\title{
Trimetazidin prolong hatásossága különbözö életkorokban az ONECAPS-vizsgálat alapján
}

\author{
Tomcsányi János', Jánosi István², Szakács László \\ Betegápoló Irgalmasrend, Budai Irgalmasrendi Kórháza, Kardiológia, Budapest \\ ${ }^{2}$ WEB2 Research Kft., Budapest
}

Levelezési cím:

Prof. dr. Tomcsányi János, 1027 Budapest, Árpád fejedelem u. 7.

E-mail: tomcsanyij@gmail.com

Az ONECAPS-betegpopulációban a trimetazidin prolong napi egyszer 80 mg alkalmazásának hatását vizsgáltuk különböző életkorokban a stabil anginás betegeknél.

Az 1701 beteget három csoportra osztottuk: 1. 60 év alatt (294), 2. 60-70 év közöttiek (667), 3. 70 év felettiek (740). A jelen elemzés rámutat arra, hogy a trimetazidin prolong mindhárom életkorcsoportban szignifikánsan $(p<0,0001)$ csökkentette a heti anginák számát, úgy hogy az egyes életkorcsoportok között nem volt klinikailag értékelhető különbség. $A$ napi egyszeri trimetazidin prolong a kedvező hatást mutatott a korábban triemtazidin MR-t napjában kétszer szedőkkel szemben is $(p<0,0001)$ ugyancsak az életkortól függetlenül. Ez a hatás nagy valószínűséggel a jobb adherenciával magyarázható.

Kulcsszavak: trimetazidin prolong, stabil angina, életkor, adherencia

Effectiveness of prolonged-release trimetazidine of the ONECAPS study population stratified by age. A multicenter, prospective, observational study

Effectiveness of prolonged-release trimetazidine of the ONECAPS study population stratified by age. A multicenter, prospective, observational study.

This study evaluated the effectiveness of prolonged-release trimetazidine $80 \mathrm{mg}$ treated patient population in the ONECAPS study stratified by age. 1701 subjects with stable angina pectoris were divided into three groups: $1 .<60$ years (294), 2. 60-70 years (667), 3. >70 years (740). The findings of present study highlight, that prolonged-release trimetazidine, reduced significantly $(p<0.0001)$ the number of weekly angina attacks regardless of age.

Once a day administered prolonged-release trimetazidine was beneficial not only because of its anti-ischemic effects, but due to increased adherence compared to trimetazidine MR and that was consistent across all age groups.

Keywords: prolonged-release trimetazidine, stable angina pectoris, adherence, age

\section{Munkamegosztás:}

TJ: vizsgálat tervezése, cikk megírása; Jl: adatok feldolgozása, statisztikai elemzése; SZL: adatok feldolgozása, statisztikai elemzése. A cikket minden szerző látta és jóváhagyta.

Rövidítések:

CCS: krónikus koronáriaszindróma; MR: módosított kioldású; NG: nitroglicerin

A kézirat 2020. 06. 12-én érkezett a szerkesztőségbe, 2020. 06. 16-án került elfogadásra. 
A stabil angina pectoris, illetve újabban a krónikus koronáriaszindrómába besorolt egyik betegcsoport fontos antiiszkémiás gyógyszere a trimetazidin, amit elsősorban kiegészítendő terápiaként javasolnak stabil anginás betegeknél (1). A szer fő hatásmechanizmusa, hogy metabolikus modulátorként segíti a sejtek ATP-felhasználását. Hatását úgy fejti ki, hogy nem befolyásolja sem a vérnyomást, sem a pulzust. Ezért ideális alkotója a kombinált antianginás kezelésnek, leginkább béta-blokkolóval alkalmazzuk együtt. Kedvező hatását az anginák számának, illetve a NG használatának csökkenésére a hazai ONECAPS-vizsgálatban mutattuk be (2), amely az egyik legnagyobb betegszámú trimetazidinnel végzett vizsgálat (3). A vizsgálatot a napi egyszeri trimetazidin prolong készítménnyel végeztük.

A közelmúltban megjelent egy hazai metaanalízis stabil angina miatt trimetazidinnel kezelt betegekre, amely
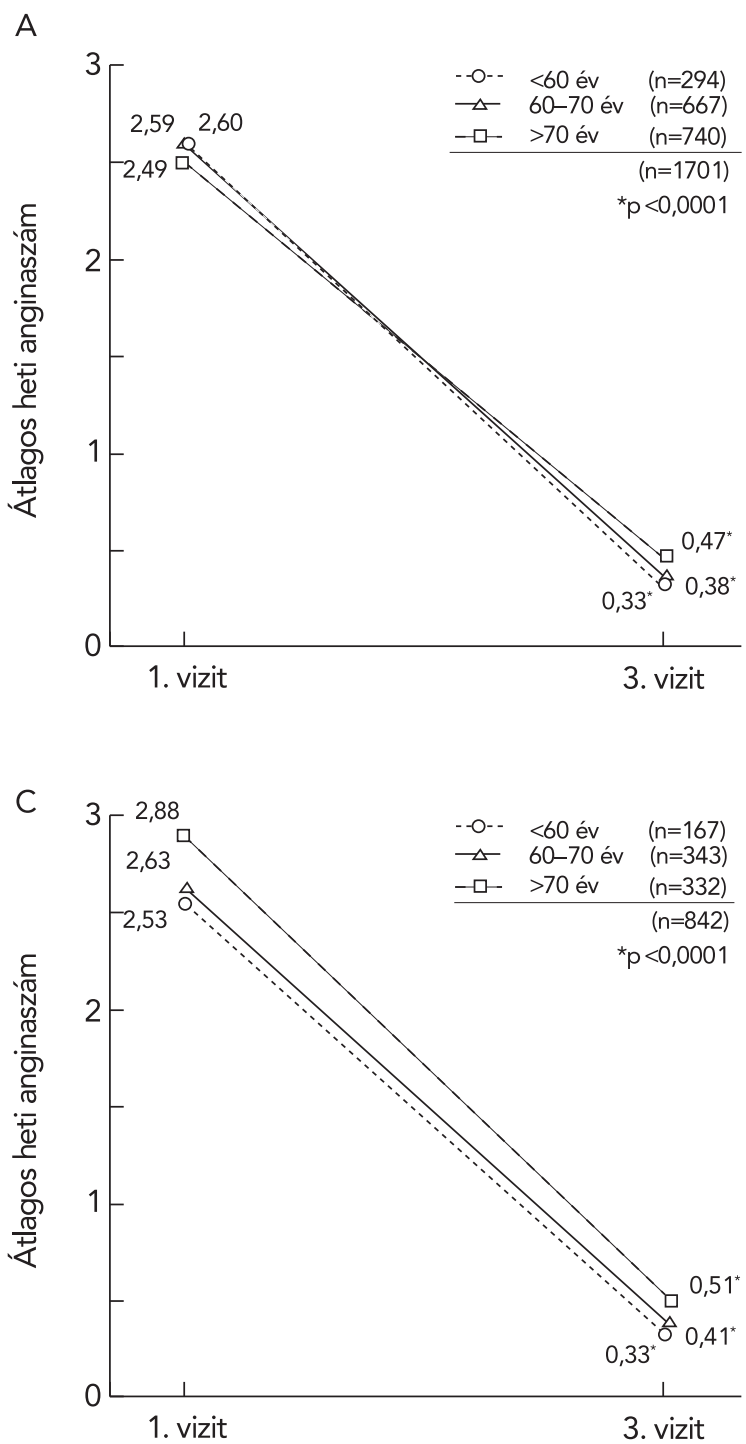

többek között azt találta, hogy a trimetazidin effektívebb fiataloknál, mint az idősebb korú populációban (3).

Ez nem érthető, és nem következik a szer hatásmechanizmusából. A metaanalízisben felhasznált irodalom tanulmányozása kérdéseket vetett fel, hogy mennyire voltak stabilak a betegek, illetve mennyire illeszthetők az ebből levont következtetések a jelenkori klinikai gyakorlatra (4). Ezért a hazai ONECAPS-vizsgálat utóelemzésén vizsgáltuk meg a trimetazidin hatásosságának és az életkornak az összefüggését.

\section{Betegek és módszer}

Az ONECAPS egy multicentrikus, obszervációs, prospektív vizsgálat volt, amely 3 hónapos időtartamot ölelt fel. Összesen 2160 betegből 1701 beteg teljesítette ma-
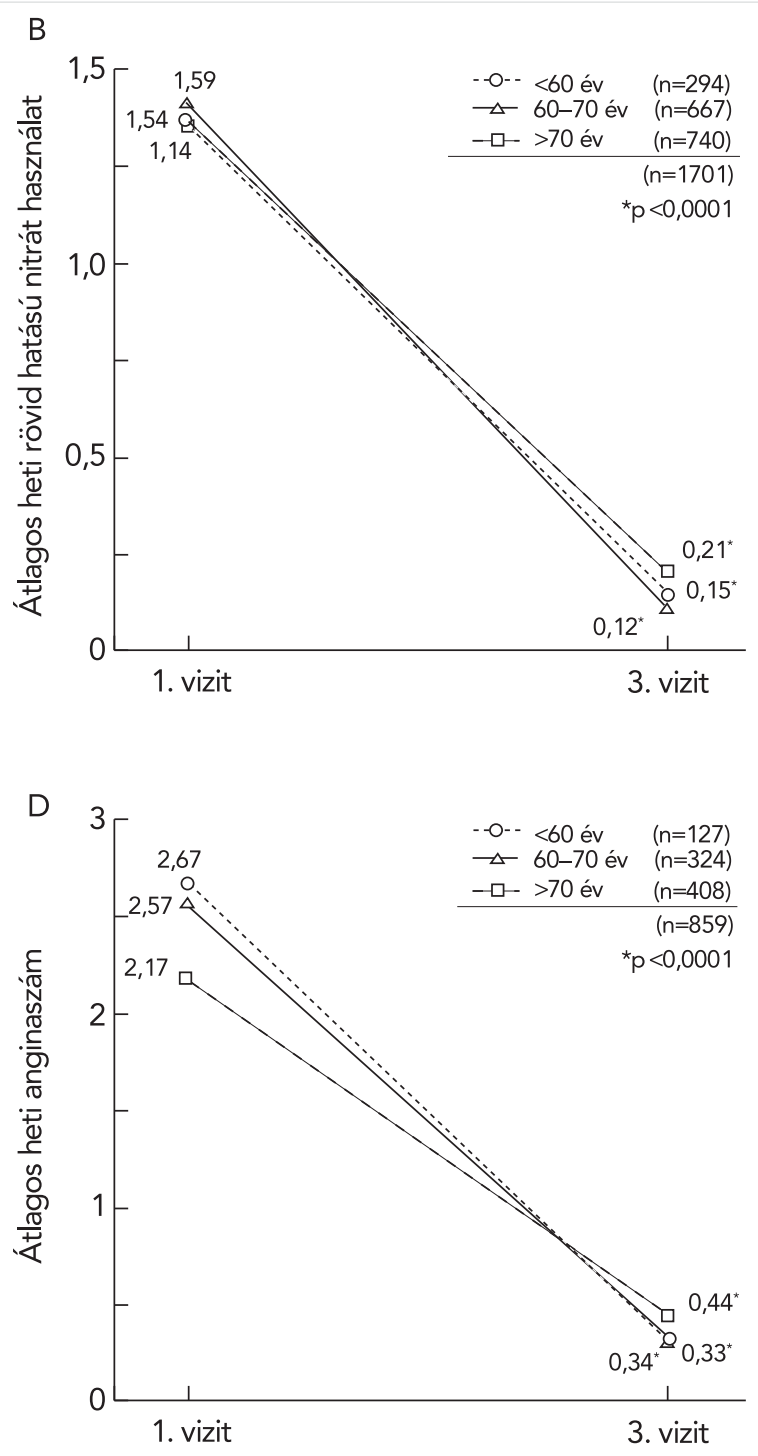

1. ÁBRA. ONECAPS-vizsgálat alapján a trimetazidin prolong $1 \times 80$ mg hatásossága a három különböző életkorcsoportban külön-külön lett vizsgálva. Az A- és B-diagram az összbeteg-populációt (1701 beteg), míg a C a trimetazidinnaiv betegek (842 beteg) trimetazidin prolongra átállítást mutatja. A D-diagram pedig a trimetazidin MR 2×35 mg-ról történő átállítást mutatják napi $1 \times 80 \mathrm{mg}$ trimetazidin prolongra (859 beteg) 
radéktalanul a vizsgálatot. Ezen betegcsoportban életkor szerint három csoportra osztottuk a betegeket: 1.60 év alatt (294 fő), 2. 60-70 év között (667), 3. 70 év felett (740 fö). A betegek átlag szérumkreatininje 81,07 $\mu \mathrm{mol} / \mathrm{l}$ volt, ami a vizsgálat végére sem változott 79,95 $\mu \mathrm{mol} / \mathrm{l}$ volt. A betegeknél napi $1 \times 80 \mathrm{mg}$ trimetazidin prolong került bevezetésre. A betegek közel fele szedett korábban trimetazidin MR-t napi 2×35 mg formában (859 fő), míg 842 fő nem szedett korábban trimetazidint. Ezért az életkor szerinti bontást a hatásosság vizsgálatára a korábban trimetazidint szedő-, és korábban nem alkalmazó betegcsoportban külön is elvégeztük.

\section{Eredmények}

Az eredményeket az 1. összefoglaló ábra mutatja be. Ebből látható, hogy az életkor szerinti mindhárom csoportban a trimetazidin prolong szignifikánsan $(p<0,0001)$ csökkentette a heti anginák-, és rövid hatású NG-fogyasztás számát, míg egymáshoz képest az egyes életkorcsoportok nem képeztek klinikailag szignifikáns különbséget. Az is megállapítható, hogy ez a hatás akkor is érvényesült, ha a beteg korábban trimetazidin MR-t szedett. Itt is független volt az életkortól a trimetazidin prolong kedvező hatása.

\section{Megbeszélés}

Az ONECAPS-vizsgálat életkor szerinti bontásban történő elemzése bizonyítja azt (amely a patomechanizmus alapján is várható volt), hogy a trimetazidin prolong a vizsgált csoportokban életkortól függetlenül hatásos. A vizsgálat statisztikai erejét a nagy betegszám adja. $A z$ egyes életkor szerinti alcsoportokban önmagában több beteg volt, mint a fent idézett metaanalízis (3) legtöbb tanulmányában. Ez rámutat a metaanalízisekben elkövetett egyik leggyakoribb hibára, hogy olyan betegvizsgálatokat tesznek egymás mellé, ahol a vizsgált készítmény egyezésén kívül az adott betegség kezelésében jelentős különbségek vannak. Ez történt a trimetazidin metaanalízis esetén is. A napi egyszeri trimetazidin prolong 80 mg-os kedvező hatását a napi kétszer 35 mg-os MR-formával szemben valószínüleg a jobb beteg adherencia adja. (A két szer gyógyszerkinetikájának összehasonlítására nincsen adatunk.) A jelen vizsgálat aktualitását adja, hogy a trimetazidinnel végzett nagy randomizált, kettős vak, randomizált vizsgálat a PCl-vel kezelt betegeknél hasonló 50-70 év közötti betegpopulációt vizsgált, aminek eredményei hamarosan várhatók (5).

\section{Következtetések}

Összefoglalva, a trimetazidinnek, mint metabolikus antiiszkémiás készítménynek fontos helye van a CCS kezelésében $(6,7)$ függetlenül az életkortól. Ugyanakkor az ONECAPS-vizsgálat alapján megállapítható, hogy a jobb betegadherenciát jelentő napi egyszeri alkalmazás alacsonyabb anginaszámot, és kevesebb rövid hatású NG-alkalmazást eredményez, mint a napi többszöri alkalmazás.

\section{Nyilatkozat}

A szerzők kijelentik, hogy az összefoglaló közlemény megírásával kapcsolatban nem áll fenn velük szemben pénzügyi vagy egyéb lényeges összeütközés, összeférhetetlenségi ok, amely befolyásolhatja a közleményben bemutatott eredményeket, az abból levont következtetéseket vagy azok értelmezését.

\section{Irodalom}

1. Knuut J, Wijns W, Saraste A, Capodanno D, et al. 2019 ESC Guidelines for the diagnosis and management of chronic coronary syndromes. The Task Force for the diagnosis and management of chronic coronary syndromes of the European Society of Cardiology (ESC). Eur Heart J 2020; 41: 407-477. DOI: 10.1093/eurheartj/ ehz425

2. Tomcsányi J, Szakács L. Effectiveness of trimetazidine prolong in stable coronary artery disease. Multicenter, prospective, observational study, ONECAPS study. (Stabil coronariabetegség kezelésére alkalmazott trimetazidin prolong hatásosságának vizsgálata. Multicentrikus, prospektív, obszervációs, nyílt klinikai vizsgálat, ONECAPS-vizsgálat.) Orv Hetil 2018; 159: 1549-1555. DOI: 10.1556/650.2018.31251

3. Nagy VL, Herald Z. Clinical effect of various trimetazidine formulations in chronic coronary syndrome. An updated systemic review and meta-analysis. (A különféle trimetazidinkészítmények klinikai hatása stabil anginával járó krónikus koszorúér-szindrómában. Frissített módszeres áttekintés és metaanalízis.) Orv Hetil 2020; 161 : 611-622. DOI: 10.1556/650.2020.31704

4. Manchanda SC, Krishnaswami S. Combination treatment with trimetazidine and diltiazem in angina pectoris. Heart 1997; 78: 353-357. DOI: 10.1136/hrt.78.4.353

5. Ferrari R, Ford I, Fox K, et al. A randomized, double-blind, placebo controlled trial to assess the efficacy and safety of Trimetazidine in patients with angina pectoris having been treated by percutaneous coronary intervention (APTCl): Rationale, design and baseline characteristics. Am Heart J 2019; 210: 98-107. DOI: 10.1016/j. ahj.2018.12.015

6. Dézsi Cs. Trimetazidine in practice: review of the clinical and experimental evidence. Am J Ther 2016; 23: e871-879. DOI: 10.1097/ MJT.0000000000000180

7. Ferrari G, Camici PG, Crea F, et al. The „diamond” approach for a personalized treatment of angina. Nat Rev Cardiol 2018; 15(2): 120-132. DOI: 10.1038/nrcardio.2017.131 